\title{
Dilema etis pekerja sosial dalam menerapkan self-determination dalam penanganan korban kekerasan di Rifka Annisa Yogyakarta
}

\section{Pebri Yanasari'}

${ }^{1}$ Institut Agama Islam Negeri Syaik Abdurrahman Siddik Bangka Belitung

Korespondensi

phebhe@yahoo.co.id

\begin{abstract}
Social worker as a profession based on help and assistance. One of them has the main task of trying to solve problems for individuals and groups. In handling it, social workers are the same as other professions, namely having a certain code of ethics in providing services to their clients. With regard to violence against women, the values and ethics of social workers can be applied in dealing with this problem. The method used in this research is descriptive qualitative, the data obtained from the results of interviews with institutions. For the approach, researchers used a phenomenology approach. The sources come from media references and other supporting books. In this case, the social worker at Rifka Annisa Yogyakarta tries to be wise and neutral towards the client in establishing a good relationship with the client's problems. The series of mentoring received by the client ends when the client / victim has carried out Self-Determination (selfdetermination) where the final decision is determined by the client / victim so that in handling the social worker experiences a dilemma when the decision is not in line with the process that has been done with the client.

\section{KEYWORDS:}

Dilemma, Self-determination, Victims of violence
\end{abstract}




Abstrak
Pekerja sosial sebagai salah satu profesi yang berbasiskan
pertolongan dan pendampingan. Salah satunya memiliki
tugas pokok mengupayakan dalam menyelesaikan
permasalahan bagi individu maupun kelompok. Dalam
penanganannya, pekerja sosial sama halnya dengan profesi
lain yaitu memiliki kode etik tertentu dalam memberikan
pelayanan kepada kliennya. Berkenaan dengan kekerasan
terhadap perempuan maka nilai dan etika pekerja sosial
dapat diterapkan dalam menangani permasalahan ini.
Metode yang digunakan dalam penelitian ini adalah
deskriptif kualitatif, data yang diperoleh dari hasi
wawancara dengan lembaga. Untuk pendekatan, peneliti
menggunakan pendekatan fonomenologi. Adapun sumber
berasal dari referensi media maupun buku penunjang
lainnya. Dalam kasus ini pekerja sosial yang ada di Rifka
Annisa berusaha bersikap bijak dan netral kepada klien
dalam menjalin hubungan yang baik dengan kaitaannya
permasalahan klien. Rangkaian pendampingan yang
didapatkan oleh klien berakhir ketika klien/korban sudah
melakukan Self- Determination (menentukan pilihan
sendiri) dimana keputusan akhir ditentukan oleh
klien/korban sehingga dalam penanganannya pekerja sosial
mengalami dilema ketika keputusan tidak seiring dengan
proses yang sudah dilakukan bersama klien.
KATA KUNCl:
Dilema, Self-determination, Korban kekerasan.




\section{1 | Pendahuluan}

Tempat yang strategis dalam membentuk karakter dan watak kepribadian seseorang adalah keluarga. Dibutuhkan relasi sosisal yang baik dalam pergaulan di masyarakat yang dimulai dari lingkup keluarga yang merupakan sekolah dimana para putra dan putri bangsa belajar dalam mengenal sifat-sifat yang baik seperti kesetiaan, kasih sayang, kejujuran, kedisiplinan dan lainnya. Upaya tersebut memang membutuhkan usaha dan kerjasama yang baik pula dari anggota keluarga.

$$
\text { Dalam masyarakat, keluarga }
$$
merupakan pondasi awal yang menjadi landasan dukungan untuk lahirnya bangsa dan masyarakat. Selama landasan itu dapat membangkitkan arus yang sehat dan kuat maka dapat dipastikan juga bahwa masyarakat bangsa menjadi sehat dan kuat [1] namun jika dalam keluarga seseorang pernah mengalami kekerasan maka di saat itulah keadaan akan menjadikan seorang individu memiliki pemahaman bahwa kekerasan boleh dilakukan. Kekerasan merupakan penindasan dari suatu pihak ke pada pihak lain dan dianggap ketidaksetaraan dalam masyarakat. Kekerasan yang dikenal dengan domestic violence merupakan bentuk penindasan (abuse) oleh suami kepada istri baik secara fisik maupun psikis termasuk di dalamnya mengambil hak untuk merasa nyaman dalam suatu keadaan. Namun tindakan kekerasan tidak hanya terjadi antara suami terhadap istrinya, tapi bisa terjadi juga pada orangtua terhadap anak atau antara majikan dan asisten rumah tangga dalam lingkup keluarga.

Dalam lingkup keluarga kekerasan merupakan salah satu pelanggaran hak asasi manusia dan dikelompokkan kejahatan kemanusiaan dan tentunya merupakan salah satu dalam bentuk diskriminasi. Semua orang memiliki potensi menjadi pelaku maupun korban dalam kekerasan yang tentunya tidak memperhatikan status ekonomi, status sosial, usia, jenis kelamin, suku, tingkat pendidikan bahkan agama. Komisi Nasional (KOMNAS) [2] Perempuan mencatat dalam pelaporan kasus Kekerasan Dalam Rumah Tangga (KDRT) selain menggambarkan adanya peningkatan jumlah kasus kekerasan dalam rumah tangga dari tahun ke tahun juga menunjukkan bahwa di antara para korban bersal dari istri, yaitu 25.788 kasus 
dari total korban. Sedangkan anak perempuan berada pada tingkat ke-3 dengan jumlah kasus 1.693 setelah pacar sebanyak 2548 kasus sedangkan untuk kasus terendah pada pembantu rumah tangga sebanyak 467 kasus [3].

Identifikasi kekerasan terhadap perempuan dan anak dilakukan melalui Pengadilan Agama, Kepolisian, Rumah Sakit Umum, Pengadilan Negeri dan Lembaga Swadaya Masyarakat (LSM).

Dari hasil pemetaan terhadap kekerasan perempuan dan anak, diperoleh data sebagai berikut [4].

TABEL 1 Data Kekerasan

\begin{tabular}{|l|c|c|c|c|c|c|}
\hline $\begin{array}{l}\text { Bentuk } \\
\text { KDRT }\end{array}$ & Pol & Jak & PN & PA & RSU & LSM \\
\hline KDRT & 73 & 13 & 36 & 14645 & - & - \\
\hline $\begin{array}{l}\text { Perkosa } \\
\text { an }\end{array}$ & 124 & 66 & 74 & - & 98 & - \\
\hline $\begin{array}{l}\text { Peleceh } \\
\text { an }\end{array}$ & 69 & 56 & 44 & - & - & - \\
\hline $\begin{array}{l}\text { Kekerasan } \\
\text { dalam } \\
\text { relasi } \\
\text { personal }\end{array}$ & 6 & 1 & 10 & - & 7 & 61 \\
\hline
\end{tabular}

Berdasarkan hasil penanganan KOMNAS

Perempuan dari kasus kekerasan yang terdapat pada 14 daerah di Indonesia tercatat sebanyak 3169 kasus kekerasan pada perempuan, dimana perempuan paling banyak mengalami kekerkasan dan penganiayaan oleh orang terdekat mereka sendiri (40\%), disusul dengan tindakan pemerkosaan pada komunitasnya sendiri (32\%). Pola ini tidak hanya saja terjadi di kota-kota besar seperti Jakarta dan Yogyakarta yang terbiasa dengan konflik, namun juga di Surabaya, dan Sulawesi Selatan yang juga diwarnai dengan kedinamisan ekonomi serta budaya. Berdasarkan data di atas masih banyaknya kasus perkosaan dan Kekerasan dalam Rumah Tangga yang dialami oleh perempuan. Terlebih masih banyak kasus di daerah yang kurang mendapatkan perhatian sehingga para korban KDRT dan perkosaan tidak terdata secara merata.

Saur Tumiur sebagai Komisioner Komisi Nasional Perempuan mengatakan bahwa Indonesia sedang berada dalam kondisi kekerasan terhadap perempuan zona merah. Hal tersebut tanpa alasan, tentunya dikarenakan semakin meningkatnya angka kekerasan dari tahun ke tahun. "Fenomena gunung es ini sangat mengkhawatirkan" Pada tahun 2014 jumlah kekerasan terhadap perempuan sebanyak 293.220 kasus. Jumlah tersebut meningkat 
dibandingkan tahun 2013 sebanyak 279.688 kasus. Data di atas tentunya menjadikan perempuan dalam ranah domestik maupun publik masih tergolong tidak aman. Pekerjaan sosial memiliki peran dalam mendampingi dan memberikan pelayanan bagi para perempuan korban kekerasan diatas.

Dalam pelayanannya dalam hal mendampingi, pekerja sosial memiliki etika yang harus diperhatikan terhadap perempuan korban kekerasan. Namun dalam penerapannya, nilai dan etika tersebut harus melalui proses yang tidak mudah. Maka dari itu pekerja sosial dituntut untuk profesional dalam mendampingi klien. Perempuan korban kekerasan memiliki sifat sensitif dan keadaan yang rentan secara fisik maupun mental, maka dibutuhkan etika yang tepat dalam menangani kasus kekerasan pada perempuan. Pekerja sosial juga memiliki nilai yang harus diterapkan dalam menciptakan suasana para korban kekerasan mampu memberikan data sedetail mungkin. Sikap komunikatif dan responsif sangat dibutuhkan dalam menangani perempuan korban kekerasan, dikarenakan sarana yang komunikatif mampu memberikan efek keterbukaan klien kepada pekerja sosial. Komunikatif juga dibutuhkan untuk mencari celah untuk masuk dalam ranah korban kekerasan agar mereka merasa didampingi dengan baik. Selain komunikatif, juga dibutuhkan sikap responsif, yang mana dengan sikap ini pekerja sosial mengemukakan bahwa masalah yang sedang dihadapi klien bisa diselesaikan bersama dan bukan masalah pribadi yang tidak bisa diselesaikan. Ini penting, mengingat tingkat kepercayaan diri klien perempuan korban kekerasan mengalami ketidakstabilan. Maka kondisi ketidakstabilan dapat memengaruhi perempuan kekerasan dalam mengambil keputusan secara matang dan pada akhirnya memengaruhi pekerja sosial dalam memberikan pelayanan.

Rifka Annisa yang diinisiasi oleh beberapa aktivis perempuan hadir karena keprihatinan terhadap budaya patriarkhi memperlemah posisi perempuan hadir sebagai wadah bagi para korban kekerasan untuk dapat menyelesaikan permasalahannya dalam rangka penghapusan kekerasan terhadap perempuan. Dalam struktur organisasi Rifka Annisa terdapat bidang pendampingan yang biasanya tidak 
hanya dilakukan oleh para konselor dan psikolog namun pekerja sosial. Rifka Annisa yang merupakan salah satu penggerak dalam upaya penghapusan kekerasan terhadap perempuan, diperlukan pola kerja pengorganisasian dalam bentuk pendampingan. Pendampingan tersebut dilakukan dengan tujuan agar masyarakat dapat mempunyai kesadaran tentang kesetaraan gender serta kesadaran untuk tidak melakukan kekerasan terhadap perempuan.

Tulisan ini hadir untuk memberikan gambaran tentang dilema pekerja sosial dalam menerapkan selfdetermination terhadap korban kekerasan. Sehingga dalam penanganannya, pekerja sosial memiliki langkah strategis dalam memberikan layanan kepada perempuan korban kekerasan. Rifka Annisa dalam pengembangan sumberdaya bagi penghapusan kekerasan terhadap perempuan menyediakan berbagai layanan dan kegiatan seperti: layanan konsultasi dan layanan fasilitasi. Sehingga dalam pelayanannya, Rifka Annisa tidak hanya memberikan layanan konsultasi namun juga layanan fasilitas. Layanan fasilitasi memberikan pencegahan dan penanganan kekerasan terhadap perempuan berbasis gender, sosialisasi gender, konseling dan pelibatan laki-laki.

\section{Metode}

\section{a. Analisis Data}

Metode merupakan suatu langkah dalam upaya mencari tahu sesuatu tentunya memiliki cara-cara yang terukur dan terarah. Metode analisis data yang digunakan pada penelitian ini masuk pada analisis deskriptif kualitatif yang mana penyajian data dalam rangkaian tulisan bukan pada rangkaian angka tentunya apa adanya sesuai dengan data yang diperoleh dari penelitian yang sudah dilakukan. Sedangkan teknik analisis data yang telah digunakan dalam penelitian ini mengacu pada konsep Matthew B. Miles dan A. Michael Huberman yaitu [5]:

\section{1) Reduksi data}

Reduksi merupakan suatu alur dari langkah pemilahan, mengkhususkan penelitian pada penyederhanaan, transformasi data mentah yang muncul dari data-data tertulis dalam bentuk catatan selama di lapangan. Dalam prosesnya reduksi data secara berkelanjutan dilakukan selama penelitian berlangsung. 
2) Penyajian data

Penyajian data yang merupakan lingkupan berbagai informasi yang tersusun sehingga memiliki kemungkinan adanya tindakan yang dapat dilakukan. Bentuk dari penyajian data biasanya digunakan pada data kualitatif yang berbentuk teks narasi.

\section{3) Menarik kesimpulan/verifikasi}

Dalam menarik kesimpulan atas pemaknaan objek dan subjek penelitian, terdapat pula pola-pola, penjelasan serta alur pada sebab akibat pada penyajian data sebelumnya. Sedangkan analisis yang berasal dari peneliti dilakukan dengan cara mengumpulkan data yang didapat terlebih dahulu sehingga dapat dilakukan penyusunan dan klarifikasi, selanjutnya dianalisis membentuk kalimat sederhana dan dapat dipahami sehingga pada akhirnya untuk mencapai kesimpulan sebagai hasil dari penelitian.

b. Pendekatan Penelitian

Penelitian ini mengarah kepada pendekatan fenomenologis dan tekstual. Diharapkan dengan pendekatan ini dapat ditemukan variabel tertentu yang diinginkan peneliti cari dengan melihat fenomena-fenomena kekerasan terhadap perempuan yang ada khususnya dalam penelitian ini di Rifka Annisa yang terletak di Yogyakarta. Tentunya pendekatan fenomenologi ini merupakan gambaran kehidupan sosial yang terjadi di masyarakat sehingga penelitian ini benar-benar bersumber pada kejadian yang dialami oleh seorang individu.

c. Sumber Data

Sumber data dalam penelitian ini adalah data-data primer yang dikumpulkan dari hasil wawancara dan kajian serta telaah dari fenomena yang ada. Selain itu dilengkapi dari rujukan buku-buku yang berkaitan dengan masalah yang diangkat dalam penelitian ini sehingga kajian kepustakaan dan fenomena yang ada dapat disinkronkan.

\section{3 | Hasil dan Pembahasan}

Dalam menerapkan proses nilai dan etika merupakan permasalahan yang darurat dalam tuntunan praktik pekerjaan sosial. Nilai-nilai yang harus kita terapkan merupakan landasan utama bagi pekerja sosial dalam memahami ketika praktik diterapkan. Sebagai contohnya adalah bahwa kasus yang sedang dihadapi oleh para klien dan berusaha mencari bantuan cenderung 
adanya kaitan mengenai perbedaan nilai antara individu dengan individu atau antara individu dan kelompok dimana lingkungan mereka tinggal. Pemahaman tentang nilai dan etika yang baik berdampak pada para pekerja sosial dalam mengambil suatu keputusan dalam menangani suatu perkara sehingga tidak jarang berdampak pada terjadinya dilema etis yang memiliki peran penting dalam membuat keputusan etik yang tepat dan akurat. Fokus permasalahan dalam penelitian ini adalah bagaimana Implementasi nilai dan etika pekerja sosial dalam penanganan korban kekerasan di Rifka Annisa.

Nilai berasal dari bahasa latin valere yang artinya "menjadi kuat atau menjadi terhormat". Untuk menjadi terhormat diperlukan suatu pedoman perilaku yang baik dengan yang buruk. Soetarso mengatakan bahwa nilai adalah kepercayaan, pilihan atau asumsi tentang yang baik untuk manusia [6]. Sedangkan Pincus dan Minahan menyatakan nilai [7], adalah keyakinan, preferensi ataupun asumsi mengenai apa yang diinginkan atau dianggap baik oleh manusia. Nilai yang dianut oleh seseorang dapat menentukan sikap dan tindakan seseorang dalam berinteraksi dengan orang lain.

Nilai dan etika yang diterapkan secara benar berdampak pada pengambilan suatu keputusan dalam menentukan langkah tertentu yang akan diambil oleh para pekerja sosial. Nilai yang dimaksud merupakan seperangkat prinsip etik/moral fundamental dimana pekerja sosial harus berkomitmen dalam menjalankan prinsip pekerjaan sosial [8].

\subsection{Nilai dan Etika Pekerjaan Sosial}

Zastrow dalam Edi Suharto mendefinisikan pekerjaan sosial adalah aktivitas profesional untuk menolong individu, kelompok dan masyarakat dalam meningkatkan atau memperbaiki kapasitas mereka agar berfungsi sosial dan menciptakan kondisi-kondisi masyarakat yang kondusif untuk mencapai tujuan tersebut [9]. Sebagai suatu aktivitas profesional, kesejahteraan sosial khususnya pekerjaan sosial didasari oleh tiga komponen dasar yang secara integratif membentuk profil dan pendekatan pekerjaan sosial, pertama, kerangka pengetahuan (body of knowledge), kedua kerangka keahlian (body of skill), dan ketiga kerangka nilai (body of values). Ketiga komponen 
tersebut dibentuk dan dikembangkan secara ekletik dari beberapa ilmu sosial seperti sosiologi, psikologi, antropologi, filsafat, politik dan ekonomi. Dalam konferensi dunia di Montreal Kanada, Juli tahun 2000, International Federation of Social Worker (IFSW) [10] mendefinisikan pekerjaan sosial sebagai berikut:

"Profesi pekerjaan sosial mendorong pemecahan masalah dalam kaitannya dengan relasi kemanusiaan, perubahan sosial, pemberdayaan dan pembebasan manusia, serta perbaikan masyarakat. Menggunakan teori-teori perilaku manusia dan sistem-sistem sosial, pekerjaan sosial melakukan intervensi pada titik (atau situasi) di mana orang berinteraksi dengan lingkungannya. Prinsip-prinsip hak asasi manusia dan keadilan sosial sangat penting bagi pekerjaan sosial"

Sedangkan nilai-nilai dasar dalam pekerja sosial sendiri pada awalnya banyak dipengaruhi oleh nilai yang berkembang pada 'profesi yang memberikan bantuan terhadap masyarakat' (helping profession) lainnya. Karena itu ada beberapa nilai yang terkait dalam relasi profesional antara sarjana kesejahteraan sosial dan sarjana pekerjaan sosial sebagai agen perubahan (pihak yang mencoba melakukan perubahan sosial) dengan benefeciaries (pihak yang menerima layanan) ataupun komunitas sasaran mereka. Beberapa nilai tersebut antara lain: Pertama, agen perubahan (change agent) dalam hal ini sarjana kesejahteraan sosial dan pekerjaan sosial harus mempertimbangkan bahwa setiap manusia mempunyai hak untuk memenuhi kebutuhan dasarnya, dengan memperhatikan hak anggota masyarakat yang lain. Kedua, agen perubahan harus mempertimbangkan bahwa setiap warga masyarakat berhak untuk mendapatkan perlindungan dan kesempatan dalam memenuhi hak-hak dan kebebasan asasinya dan sejalan dengan kepentingan bersama (tidak bertentangan dengan norma masyarakat secara umum). Ketiga, harus memperhatikan unsur kesinambungan dari program perubahan sosial terencana. Keempat, agen perubahan tidak seharusnya terjadi hubungan yang eksploitatif di antara mereka. 
Adapun nilai dalam praktik pekerja sosial secara teori sebagai berikut:

1) Penerimaan / Acceptance

Pada dasarnya prinsip ini memandang pekerja sosial dituntut untuk dapat meneria klien dengan apa adanya mereka tanpa memberikan penghakiman kepada klien tersebut. Dalam hal ini tidak melihat klien secara penglihatan fisik saja, misalkan dari cara berpakaian. Padahal berdasarkan prinsip penerimaan ini seorang pekerja sosial sebisa mungkin dapat meredam perasaan 'suka' atau 'tidak suka' yang terlihat dari fisik penampilan seorang klien.

2) Komunikasi/ Communication

Pada prinsip ini komunikasi yang dibangun antara pekerja sosial dan klien sebisa mungkin dapat dijaga sebaik mungkin. Mimik wajah klien dapat diartikan sebagai pesan dari apa yang dikomunikasikan. Oleh karena itu, pekerja sosial diharapkan mampu meng-explore (mencari tahu sebanyak mungkin) keadaan serta bagaimana perasaan yang sedang dirasakan klien dan harapan klien terhadap penyelesaian masalahnya.

3) Individualisasi / Individualisation

Pada prinsip individualistic ini pekerja sosial diharapkan mampu membedakan keadaan setiap diri klien dengan klien lainnya, sehingga pekerja sosial dalam praktiknya bisa berusaha mengetahui keunikan tersendiri dari setiap diri klien. Sehingga dibutuhkan intervensi yang sesuai dengan kondisi klien yang sedang dihadapi sehingga bisa mendapatkan hasil yang optimal dalam penanganan.

\section{4) Partisipasi / Participation}

Partisipasi yang dimaksud adalah pekerja sosial dituntut untuk dapat menjalankan peran sebagai fasilitator sehingga diharapkan dapat membawa klien untuk berperan aktif dan optimis dalam menghadapi permasalahan yang dihadapinya.

\section{5) Kerahasiaan / Confidentiality}

Kerahasiaan ini tentunya hal yang sangat penting, yaitu pekerja sosial dituntut mampu menjaga rahasia dengan apa yang didapatkan dari permasalahan klien dengan tidak mengekspos permasalahan klien di ranah publik sehingga tidak memberikan dampak negatif terhadap diri klien.

6) Kesadaran diri pekerja sosial (bersikap profesional).

Tentunya hal ini dikarenakan pekerja sosial dituntut tidak mencampuri 
urusan pribadinya dengan urusan pribadi seorang klien yang dihadapi.

\section{2 |Dilema Etis Pekerja Sosial Pada Perempuan Korban Kekerasan}

\section{Pengertian}

Menjadi seorang pekerja sosial memang bukanlah suatu pekerjaan yang mudah semudah membalikkan telapak tangan. Sebagai seorang pekerja sosial memiliki sebuah kode etik yang diatur untuk melindungi dan menjaga diri sebagai pekerja sosial. Namun, dalam aplikasinya dengan klien terkadang kita memiliki sebuah dilema yang tidak mudah untuk kita pecahkan.

Menurut WJS Poerwadarminta: 1976, dilema ialah situasi yang mengharuskan seseorang melakukan pilihan antara dua kemungkinan yang kedua-duanya tidak menyenangkan; Situasi yang sukar dan membingungkan. Sementara dilema etik memiliki pengertian yaitu suatu keadaan dimana seseorang dihadapkan pada situasi yang memerlukan pilihan antara nilai yang penting secara seimbang. Dilema etis seringkali terjadi ketika pekerja sosial memandang dirinya dihadapkan kepada pilihan antara dua hal yang sama-sama merupakan pilihan yang tidak dapat diterima, yang mungkin akan menyebabkan konflik prinsip-prinsip moral dengan tidak jelas pilihan mana yang benar. Jadi yang dinamakan dilema ialah merupakan persoalan teknis bagi seseorang bisa saja merupakan persoalan etis bagi yang lain atau merupakan dilema bagi pihak ketiga. Hal ini tergantung dari bagaimana seseorang melihat situasinya, bagaimana pengalaman mengajarkannya membuat keputusan moral dan bagaimana pengalaman mempengaruhi prinsip moral mereka. Contoh persoalan yang biasa terjadi dan menjadikan dilema ialah ketika seorang pekerja sosial memahami bahwa harus mendapatkan persetujuan dari klien untuk memberikan informasi, menghargai hak klien untuk menentukan bagi dirinya sendiri dan patuh terhadap aturan yang ada selama proses pendampingan berlangsung. Dengan demikian, jika dihadapkan dengan dilema etis, pekerja sosial mampu menentukan tindakan yang prioritas.

Dilema etis dalam pekerjaan sosial mempunyai berbagai bentuk. Terdapat dilema etis terkait intervensi langsung terhadap klien yaitu dalam pemberian pelayanan individu, keluarga dan kelompok kecil. Selain itu ada yang terkait 
dengan praktik komunitas, tindakan sosial, administrasi, penelitian dan evaluasi, relasi rekan sejawat dan pendidikan profesional [11].

Dilema etis tentunya dirasakan oleh setiap pekerja sosial dalam memberikan layanan kepada klien, terlepas yang berdampak bagi personal pekerja sosial maupun secara lembaga. Namun dalam penangannya pekerja sosial dituntut untuk profesional karena diharapkan dapat memberikan pelayanan yang terbaik bagi klien. Terlepas hal tersebut diterima atau tidak secara personal bagi pekerja sosial. Pelayanan yang baik tidak terlepas daripada dapat menyelesaikan permasalahan klien dengan baik.

\section{Hasil Penelitian dari Permasalahan di Rifka Annisa}

Berbagai pengertian umum mengenai dilema etis di atas ialah berbagai kemungkinan yang dapat temui dalam pengaplikasian terhadap klien di lapangan. Dalam pembahasan ini, peneliti memfokuskan pembahasan mengenai dilema yang dihadapi dalam penanganan kasus yang menjadikan perempuan sebagai korbannya. Salah satu contoh yang dapat dijadikan pelajaran bahwa telah ketahui bersama pada Maret 2015 lalu, Kementrian Pemberdayaan Perempuan dan Anak telah mendeklarasikan bahwa Indonesia Darurat Kekerasan pada Perempuan, disusul pada Bulan November/ Desember Kementrian Pemberdayaan Perempuan dan Anak juga mengumumkan bahwa Indonesia mengalami Darurat Kekerasan Seksual pada Anak. Hal ini didasari dengan jumlah kekerasan pada perempuan tahun 2014 mencapai 293.220, angka yang terbilang fantastis karena jumlah kekerasan pada perempuan setiap tahunnya senantiasa mengalami kenaikan terus menerus. Tentunya kasus tersebut harus menjadi perhatian bersama terhadap kekerasan pada perempuan, baik di ranah domestik maupun ranah publik. Kasus yang berhubungan dengan keluarga merupakan salah satu kasus domestik yang secara sosio kultur dikontruksikan sebagai ranahnya perempuan, terkadang disinilah pekerja sosial mengalami dilema dalam menyelesaikan suatu kasus [12] hal ini disebabkan karena sifat tertutup dari para korban dan pelaku. Dalam hal ini perempuan cenderung lebih luluh jika bisa diselesaikan secara kekeluargaan. 
Di Indonesia khususnya, kini sudah menyebar banyak sekali lembagalembaga yang memfokuskan dirinya terhadap perlindungan anak dan perempuan. Hal ini mungkin didasari dengan stigma bahwa anak dan perempuan ialah kelompok rentan yang sering mendapat perlakuan yang tidak baik dan memang harus dilindungi. Oleh karena itu banyak sekali LSM yang kini menaungi perempuan sebagai korban kekerasan, entah itu bersifat menetap di lembaga tersebut atau hanya sebatas konsultasi dan sharing. Di Yogyakarta ada sebuah lembaga yang sudah cukup terkenal yaitu Rifka Annisa, lembaga ini memfokuskan dirinya juga pada kasus perlindungan anak dan perempuan. Dari hasil wawancara yang kami lakukan dengan kepala bidang staff pengorganisasian, ada beberapa dilema yang seringkali dihadapi ketika proses penyelesaian masalah dan pendampingan terhadap klien. Berbagai permasalahan tersebut dapat dikategorikan menjadi tiga pokok, yaitu: Pertama, permasalahan hak individu dan kesejahtaraan klien. Kedua, Hak klien untuk membuat keputusan dan pilihan sendiri. Ketiga, Tanggungjawab pekerja sosial untuk kesejahteraan klien.

Dalam hal pendampingan klien, pekerja sosial tidak diperkenankan untuk menekankan penyelesaian permasalahan dengan cara intervensi terhadap klien untuk dapat mengikuti saran pekerja sosial hal tersebut menyangkut hak klien sebagai individu dalam membuat keputusan dan pilihannya sendiri. Ranah pekerja sosial sebatas mendampingi dan memberikan arahan serta masukan terhadap permasalahan klien.

\section{Penyelesaian}

Dalam Keraf ada dua teori yang dapat digunakan dalam mengambil keputusan ketika menghadapi dilema etik bagi pekerja sosial

\section{a. Etika Deontologi}

Deontologi pada hakikatnya merupakan tindakan yang dianggap baik berdasarkan tindakan itu sendiri dan bukan berdasarkan tujuan serta dampak dari perbuatan tersebut. Hal itu dapat pada kasus menjaga kerahasiaan klien, terlepas hal tersebut akan berdampak buruk dalam menjaga kerahasiaan klien namun hal tersebut baik karena pekerja sosial telah melakukan kewajiban dalam 
mentaaati hukum atau kode etik yang berlaku.

b. Etika Teleologi

Etika teleologi memiliki tolak belakang dengan etika deontologi. Etika ini lebih memfokuskan terhadap dampak terlepas dampak baik dan buruk yang akan terjadi dari tindakan tersebut. Etika ini diidentikkan dengan baik buruknya sesuatu berdasarkan berguna atau tidaknya. Pada hakikatnya tidak ada aturan yang pasti bagi pekerja sosial untuk memilih teori mana yang harus digunakan. Namun, semua kembali pada nilai yang dianut oleh pekerja sosial masing-masing. Miftachul Huda menuturkan bahwa terdapat 3 kunci dalam memahami definisi pekerja sosial. Pertama terdapat aktivitas profesional yaitu aktivitas yang dibekali dengan standar keilmuan sosial (profesionalisme). Kedua, masalah sosial. Pekerja sosial memiliki kewajiban dalam menyelesaikan masalah sosial di berbagai tingkatan ilmu yang diperoleh secara akademis. Ketiga, kesejahteraan. Dalam praktiknya capaian ke arah kesejahteraan merupakan tujuan utama yang ingin didapatkan [13].

\section{3 |Kekerasan terhadap}

\section{Perempuan}

Definisi kekerasan di dalam Peraturan Daerah Tentang Perlindungan Perempuan Dan Anak Korban Kekerasan [14] adalah setiap perbuatan yang berakibat atau dapat mengakibatkan kesengsaraan atau penderitaan baik fisik, seksual, ekonomi, sosial, dan psikis terhadap korban. Sedangkan perempuan adalah seseorang yang berjenis kelamin perempuan. Jadi, kekerasan terhadap perempuan adalah setiap tindakan yang berakibat atau mungkin berakibat kesengsaraan atau penderitaan perempuan secara fisik, seksual, ekonomi, sosial, psikis, termasuk ancaman tindakan tertentu, pemaksaan atau perampasan kemerdekaan, baik yang terjadi di depan umum atau kehidupan pribadi.

1. Jenis-jenis kekerasan terhadap perempuan

Di bawah ini adalah jenis-jenis kekerasan terhadap perempuan [15]:

a. Kekerasan fisik yaitu perbuatan yang dapat mengakibatkan rasa sakit, jatuh sakit, atau luka berat, contohnya seperti: menampar, memukul, menjambak, 
menendang, dan segala tindakan yang mengakibatkan luka fisik.

b. Kekerasan psikologi yaitu perbuatan yang mengakibatkan ketakutan, hilangnya rasa percaya diri, hilangnya kemampuan untuk bertindak, rsa tidak berdaya, dan atau penderitaan psikis berat pada seseorang. Misalnya umpatan, ejekan, cemoohan, bentakan, hinaan dan segala tindakan yang mengakibatkan tekanan psikologis termasuk ancaman, pembatasan gerak dan pengekangan, mengisolasi dari keluarga dan teman, mengancam untuk menyakiti, meninggalkan pasangan untuk selingkuh ataupun poligami.

c. Kekerasan seksual yaitu pemaksaan hubungan seksual, pemaksaan berhubungan seksual dengan orang lain untuk tujuan komersial dan atau tujuan tertentu. Termasuk kekerasan seksual adalah perusakan organ reproduksi serta pemaksaan hubungan seksual pada saat tidak diinginkan atau dengan cara yang tidak disukai. Seperti pemaksaan hubungan seksual pada saat menstruasi atau pada istri tidak menginginkan, oral dan anal seks atau pemaksaan hubungan seksual dengan benda-benda asing.

d. Kekerasan ekonomi/sosial penelantaran adalah perbuatan yang mengakibatkan penelantaran, kerugian maupun ketergantungan ekonomi.

Termasuk dalam kekerasan ekonomi atau penelantaran ini adalah:

1) Menelantarkan orang yang menurut hukum atau Karena persetujuan atau perjanjian ia wajib member kehidupan, perawatan, atau pemeliharaan kepada orang tersebut, seperti tidak memberi nafkah pada anak dan istri yang bekerja sebagai ibu rumah tangga.

2) Memaksa untuk bekerja atau mengeksploitasi secara ekonomi.

3) Membatasi dan atau melarang bekerja sehingga korban memiliki ketergantungan 
ekonomi dan berada di bawah kendali orang lain.

Diantara semua jenis kekerasan di atas, studi kasus yang ditemui di Rifka Annisa didapatkan bahwa Rifka Annisa pernah berhadapan dengan kekerasan fisik, kekerasan psikologi, seksual maupun kekerasan secara ekonomi.

2. Bentuk Kekerasan terhadap Perempuan

Mengutip beberapa kekerasan dari pemikiran Johan Galtung bahwa konsep kekerasan dari Johan Galtung yang melingkupi kekerasan langsung, kekerasan struktural dan kekerasan kultural penting untuk mengidentifikasi sumber kekerasan beserta dampaknya, sehingga memungkinkan untuk mencari solusi yang lebih komprehensif. Kekerasan langsung bisa bermacammacam bentuknya. Dalam bentuk yang klasik, ia melibatkan penggunaan kekuatan fisik, seperti pembunuhan atau penyiksaan, pemerkosaan dan kekerasan seksual, juga pemukulan. Kekerasan verbal, seperti penghinaan, secara luas juga diakui sebagai kekerasan [16].

Adapun bentuk kekerasan terhadap perempuan yang biasanya kita temui di masyarakat di antaranya adalah sebagai berikut:

a. Kekerasan dalam rumah tangga yaitu segala jenis dan bentuk kekerasan sebagaimana disebutkan di atas yang terjadi dalam lingkup rumah tangga. Termasuk dalam lingkup rumah tangga ini adalah suami, istri, orang yang menetap dalam satu rumah tangga tersebut karena hubungan darah, perkawinan, persususan, pengasuhan dan perwalian, orang yang bekerja membantu rumah tangga dan menetap dalam rumah tangga tersebut.

Kekerasan terhadap perempuan dalam rumah tangga seringkali terjadi secara berulang dan bersiklus. Seringkali tidak hanya pasangan yang menjadi korban. Anak-anak juga dapat menderita secara emosional dengan melihat orang tua mereka mendapatkan kekerasan dari pasangannya. Anak-anak bisa kehilangan figur orang tua yang diidealkan, bahkan bisa kehilangan fungsi pengasuhan 
orangtuanya karena kekerasan.

Anak juga seringkali menjadi korban kekerasan dalam rumah tangga, seperti memaksa anak untuk menikah, memaksa anak bekerja, menelantarkan, maupun berbagai bentuk kekerasan lainnya yang termasuk dalam bentuk-bentuk kekerasan fisik, psikologi, seksual maupun ekonomi. Termasuk kekerasan dalam rumah tangga ini adalah incent, yaitu pemaksaan hubungan seksual terhadap anggota keluarga yang terjadi karena hubungan sedarah atau sekandung (seperti ayah, paman, saudara, kakek); atau hubungan perwalian (seperti ayah angkat/tiri, kakek angkat/tiri, saudara angkat/tiri, atau hubungan keluarga karena perkawinan atau semenda (seperti mertua dan ipar), atau hubungan keluarga secara budaya atau karena kebiasaannya dianggap sebagai keluarga seperti pekerja rumah tangga atau orang kepercayaan yang tinggal dalam satu rumah). b. Kekerasan dalam Pacaran Yaitu jenis kekerasan baik fisik, psikis, seksual, maupun ekonomi, sebagai mana disebutkan di atas, yang terjadi dalam hubungan pacaran. Termasuk kekerasan dalam pacaran ini adalah ingkar janji menikahi, pemaksaan aborsi, tidak bertanggungjawab terhadap kehamilan, dan lain sebagainya.

c. Pemerkosaan yaitu suatu perbuatan hubungan seksual tanpa persetujuan korban atau hubungan seksual yang disertai dengan anacaman, paksaan, kekerasan ataupun tipuan. Termasuk perkosaan adalah segala tindakan pemaksaan hubungan seksual, memaksa hubungan seksual dengan cara yang tidak wajar atau tidak disukai, memaksa hubungan seksual dengan orang lain untuk tujuan komersial dan atau tujuan tertentu di luar maupun di dalam pernnikahan, baik berupa penetrasi penis ke vagina, oral seks, anal seks, maupun memaksa memasukkan benda asing ke 
organ intim seseorang untuk kesenangan seksual.

d. Pelecehan seksual yaitu segala macam bentuk perilaku yang berkonotasi seksual yang dilakukan secara sepihak dan tidak diharapkan oleh korban yang dapat berakibat merendahkan martabat atau reaksi negatif seperti rasa malu, rendah diri, tersinggung, marah, dsb.

e. Perdagangan perempuan dan anak yaitu segala tindakan yang terjadi terhadap perempuan dan anak. Perempuan berupa perekrutan, pengiriman, pemindahan, penampungan atau penerimaan dengan cara ancaman, penggunaan kekerasan atau bentuk-bentuk lain dari pemaksaan, penculikan, penipuan, atau penyalahgunaan kekuasaan atau kedudukan yang renta, member atau menerima bayaran, manfaat untuk memperoleh ijin dari orang yang mempunyai wewenang atas orang lain, untuk tujuan eksploitasi seksual, pelacuran, pengemis, perbudakan atau penghambaan.
Bentuk-bentuk kekerasan diatas merupakan bentuk kekerasan yang tidak asing kita temui di masyarakat, sudah selayaknya pekerja sosial berkoordinasi dengan stakeholder terkait segera respon terhadap berbagai bentuk kekerasan terhadap perempuan. Maka peran laki-laki dan perempuan dalam kesetaraan gender sangat diperlukan dalam bentuk sosialisasi sehingga tidak mengalami ketimpangan tugas, hak dan kewajibannya di masyarakat.

3. Beberapa cara yang harus dilakukan ketika mengalami kekerasan.

Jika telah mengalami salah satu atau lebih hal di atas, maka segeralah mencari pertolongan dan dukungan. Pertolongan dan dukungan bisa didapatkan dari keluarga, teman, atau lembaga-lembaga penyedia layanan, seperti kepolisisan, rumah sakit/layanan kesehatan, lembaga pendamping perempuan korban kekerasan. Hindari menyalahkan diri sendiri, yakinlah bahwa anda berhak untuk bebas dari kekerasan. Pada saat anda sedang mengalami kekerasan atau dalam situasi krisis dan terancam:
a. Mencari perlindungan
b. Melakukan perlawanan 
c. Melakukan sesuatu untuk mengundang perhatian, seperti berteriak atau meninggalkan pesan.

d. Bila telah mengalami kekerasan seksual, jangan mandi dan bersuci dulu, segeralah memeriksakan ke layanan seksual untuk mengamankan bukti sperma pelaku dan mendapatkan layanan pencegahan kehamilan.

e. Amankan barang bukti, seperti pakaian, alat yang dugunakan saat peristiwa dan benda-benda pelaku yang tertinggal, mendokumentasikan lukaluka fisik dengan foto.

f. Amankan barang-barang berharga dan surat-surat penting bila terpaksa meninggalkan rumah untuk mencari perlindungan.

Upaya di atas dapat dilakukan untuk perlindungan bagi perempuan sehingga memiliki kesempatan dalam memperjuangkan hak sebagai korban kekerasan. Terlebih dapat membantu para pendamping dalam menangani permasalahan yang sedang dihadapi dengan data-data faktual sesuai dengan kejadian yang sesungguhnya. Hal tersebut tidak terlepas dari pengakuan perempuan korban kekerasan sebagai upaya pembelaan terhadap harga diri dan sebagai bentuk ketidakterimaan atas apa yang telah dialami.

Kekerasan terhadap perempuan bisa terjadi dimana saja seperti, lingkungan keluarga misalkan kekerasan terhadap istri dan anak. Kemudian bisa terjadi di masyarakat umum misalkan pelecehan seks oleh orang lain, praktikpraktik budaya yang merugikan perempuan/ anak perempuan. Selain itu, kekerasan dapat terjadi pada wilayah konflik/non konflik dan becana, misalkan kebijakan/fasilitas publik yang tidak peka gender yang memungkinkan untuk terjadinya kekerasan yang dilakukan oleh aparat. Hal-hal diatas dapat diberikan oleh pekerja sosial kepada klien yang belum terdampak terhadap suatu kekerasan tertentu. Itu merupakan langkah yang dapat dilakukan jika dalam posisi korban. Harus tetap menjadi fokus bagi tindak kekerasan adalah bahwasannya peran dan kedudukan permpuan di lingkungan masyarakat yang dianggap tidak sama atau sejajar dengan laki-laki, hal ini mengakibatkan menjadi suatu 'momok' bagi perempuan. Terlebih adanya rasa takut terhadap kejahatan lebih tinggi dibandingkan dengan yang dirasakan laki-laki. Dapat 
diartikan bahwa kerentanan perempuan secara kodrasi (dalam aspek jasmaniah) membuat mereka lebih tinggi [17].

Terjadinya kekerasan terhadap perempuan dapat menimbulkan beberapa dampak di bawah ini diantaranya adalah:

a. Fisik, dampak yang ditimbulkan seperti memar, cedera (mulai dari sobekan hingga patah tulang dan luka dalam), gangguan kesehatan kronis, gangguan pencernaan, perilaku seksual beresiko, gangguan makan, kehamilan yang tak diinginkan, keguguran/melahirkan bayi dengan berat badan lahir rendah, terinfeksi penyakit menular seksual, HIV/AIDS.

b. Mental, dampak yang ditimbulkan seperti depresi, ketakutan, harga diri rendah, perilaku obsestif komplusif, disfungsi seksual, gangguan stress pasca trauma.

c. Produktivitas turun yaitu sering terlambat datang ke sekolah, sulit berkonsentasi, berhalangan karena harus mendapatkan perawatan medis, atau memenuhi panggilan polisi/menghadiri sidang. d. Fatal seperti bunuh diri, membunuh/melukai pelaku, kematian karena aborsi/keguguran/AIDS.

Dari beberapa dampak diatas, bisa saja terjadi perempuan korban kekerasan mendapatkan bentuk kekerasan ganda sehingga dapat menimbulkan dampak yang merugikan berupa ancaman pembunuhan hingga kematian. Hal ini tentunya sudah berlawanan dengan Hak Asasi Manusia seorang perempuan dan wajib untuk diperjuangkan.

\section{Hasil penelitian}

Nilai yang biasanya diterapkan di Rifka Annisa yaitu disebut dengan budaya organisasi yang berorientasi kepada pengguna layanan, di antaranya adalah integritas, orientasi kepada pengguna layanan, responsive, komunikasi dan menghargai. Sedangkan untuk bidang keprofesionalan dalam pekerjaan sebagai pekerja sosial di Rifka Annisa yang harus diterapkan di antaranya: Kerjasama, tanggungjawab, pembelajaran terus menerus dan Disiplin.

Banyak kasus kekerasan terhadap perempuan yang terjadi seringkali karena korban kurang tahu mengenai informasi dan kurangnya kesadaran terhadap 
haknya. Padahal ada beberapa haknya yang dilanggar oleh pelaku. Tetapi karena tidak tahu informasi korban merasa biasa saja, kemudian di sisi lain ketika korban akan melapor, korban tidak mempunyai uang karena korban takut polisi meminta bayaran. Salah satu contoh kasus yang terjadi di salah satu desa di Kulonprogo terjadi kasus percobaan pemerkosaan, si korban kurang menyadari bahwa hal tersebut bisa di jerat hukum. Maka karena si pelaku cerdas pelaku melakukan musyawarah tetapi tanpa dialog langsung memberikan uang 2 juta kepada korban sebagai tanda damai. Korban pun menerimanya. Hal inilah yang menjadi dilema pekerja sosial. Sebagaimana ungkapan dari Rohim sebagai pekerja sosial Rifka Annisa Devisi Pengorganisasian Masyarakat dan Advokasi.

Hasil wawancara yang didapat dari Abdur Rohim sebagai pekerja Sosial di Rifka Annisa Yogyakarta adalah: Akar permasalahan yang dialami oleh para pekerja sosial di Rifka Annisa ketika menangani korban Kekerasan Dalam Rumah Tangga dan pemerkosaan adalah situasi klien yang berubah-ubah. Meskipun keputusan berada di tangan klien, namun hal itu berdampak pada nilai self determination yang membuat pekerja sosial mengalami dilema dalam mengani suatu kasus. Contoh yang dialami oleh pekerja sosial dalam mengani kasus ini adalah ketika kasus sudah ditangani dan dibawa ke jalur hukum, perempuan yang menjadi korban kekerasan secara tibatiba meminta untuk kasus yang sudah dilaporkan di tutup saja. Hal tersebut menurut penuturan korban dikarenakan sudah diselesaikan secara musyawarah dan kekeluargaan. Klien bersikap seperti itu tentunya bukan tanpa alasan, pelaku mengiming-imingi sejumlah uang konpensasi dan meminta maaf atas kesalahnnya. Dari hasil wawancara di atas dapat disimpulkan bahwa berawal dari percobaan permerkosaan dalam hal ini bentuk dari pelecehan seksual. Ketika wawancara dengan Abdur Rohim sebagai Pekerja Sosial rifka Annisa, (Yogyakarta, Minggu, 20 Desember 2016, pukul 15.00 di Kantor Rifka Annisa) klien mengadukan permasalahannya dan meminta pihak Rifka Annisa dalam menyelesaikan permasalahannya maka Rifka Annisa melakukan hal yang seharusnya dilakukan terhadap klien yaitu melakukan asesmen, intervensi dan pengumpulan 
data terkait kasus yang dilaporkan oleh klien. Namun dalam pelaksanaannya, klien/korban berusaha dipengaruhi oleh pelaku dengan diimingi sejumlah uang sebagai uang damai.

Dari hasil wawancara tersebut juga dapat kita lihat bahwa korban tidak memiliki keberanian melaporkan tindak pelecehan seksual tersebut kepada pihak kepolisian karena berkenaan dengan ketidakinginan korban dalam mengeluarkan uang atas laporannya. Namun ketika korban di iming- imingi uang damai dari pelaku, korban menjadi luluh dan mau menyelesaikan masalah tersebut dengan jalan musyawarah. Hal ini tentunya membuat pihak Rifka Annisa harus menerapkan prinsip nilai self determination yang mana harus menyerahkan setiap keputusan ke tangan klien sebagai korban.

Kasus di atas merupakan salah satu kasus yang pernah ditangani oleh pihak Rifka Annisa dalam penanganannya. Terdapat dilema terhadap pelayanan yang diberikan kepada klien. Di satu sisi Rifka Annisa bersedia membantu hingga jalur hukum jika dilanjutkan karena sudah merupakan ranah Rifka Annisa menangani kasus tersebut ketika klien atau korban melaporkan permasalahnnya. Namun dilema yang dirasakan ketika klien/korban tersebut tidak melanjurkan proses penyelesaian masalah karena lebih memilih jalan musyawarah dengan uang damai dengan pelaku. Tentunya ini membuat pekerja sosial tidak dapat memaksa jika korban sudah menentukan pilihan penyelesaian masalah sehingga dianggap kasus selesai dan ditutup.

\section{5 | Penutup}

Perempuan bukan untuk dieksploitasi namun diberdayakan dengan perempuan yang memiliki kreativitasnya dapat memilki potensi yang dapat dikembangkan. Nilai dan etika pekerja sosial di Rifka Annisa sudah memenuhi standar kode etik keprofesionalan yang digunakan secara umum. Rifka annisa sudah menjadi wadah bagi klien/korban dalam melakukan pendampingan sebagai upaya memberikan hak individu kepada klien untuk memilih keputusan yang diikuti oleh klien/korban. Dalam kasus ini pekerja sosial Rifka Annisa memberikan kebebasan kepada klien/korban kekerasan seksual tersebut berusaha bersifat objektif dan berbicara dengan 
data kepada klien sehingga terjalin hubungan saling percaya. Rangkaian pendampingan yang didapatkan oleh klien berakhir ketika klien/korban sudah melakukan Self- Determination (menentukan pilihan sendiri). Adapun beberapa dilema etis yang terjadi di lapangan yaitu self-determination. Dimana keputusan akhir ditentukan oleh klien/korban. 


\section{Daftar Pustaka}

[1] Shihab, Q. (1992). Membumikan AlQur'an. Mizan: Jakarta

[2] https://komnasperempuan.go.id/siaranpers-detail/catahu-2020-komnasperempuan-lembar-fakta-dan-poinkunci-

[3] Maria Magdalena; Ramirez Hernandez. (2004). Title. Sistem Otot, 55. http://eprints.uanl.mx/5481/1/102014999 5.PDF

[4] Mardiyanto. (2005). Kebijakan Penghapusan kekerasan Rumah TAngga di Propinsi Jawa Tengah, Makalah seminar Regional dengan tema "kebijakan Pemerintah Daerah dalam Merespon UU PKDRT, PSG STAIN Purwokert o- KPI Jateng.

[5] Miles dan Huberman. (2007). , Analisis Data Kualitatif , terj. Tjetjep Rohendi. UI Press.

[6] Soetarso,(1998). Praktek Pekerjaan Sosial. Bandung: STKS Bandung

[7] Rukminto Adi, I. (2013). Kesejahteraan Sosial. Raja Grafindo Persada. Shihab, Q. (1992). Membumikan Al-Qur'an. Mizan.

[8] Putri, N. P. (2019). Implementasi Prinsip Nilai dan Etika Pekerja Sosial dalam Penanganan Pengemis di IPSM Yogyakarta Pendahuluan permasalah kesejahteraan sosial . Menurut Badan Pusat Statistik ( BPS ) pengemis . Pengemis menurut Peraturan Kepala Kepolisian ( Perkap ) Negara. Islam Management and Empowerment Journal (IMEJ), 1(1), 63-78. http://ejournal.iainsalatiga.ac.id/index.php/imej

[9] Edi Suharto, 2006. Membangun Masyarakat Memberdayakan Rakyat
(Kajian Strategis Pembangunan Kesejahteraan Sosial dan Pekerjaan Sosial), PT. Refika Aditama: Bandung

[10] Tan, Ngoh-Tiong dan Elis Enval (2000). "Social Work" : Challenges in the New Millenium" dalam Tan dan Ellis (Ed.). Social Work Around The World. Switzerlnd: IFSW Press

[11] Harnoko, B. R. (2010). Dibalik tindak kekerasan terhadap perempuan. Muwazah, 2(1), 181-188.

[12] Sujadmi, S. (2017). PEREMPUAN DALAM ARENA KEKERASAN

[13] Huda, Miftachul,(2009). Pekerjaan Sosial dan Kesejahteraan Sosial: Sebuah Pengantar, Cetakan Pertama, Yogyakarta: Pustaka Pelajar

[14] Peraturan Daerah tentang Perlindungan Perempuan dan Anak Korban Kekerasan, Pub. L. No. Nomor 1 (2012).

[15] Rifka, A. (2016). Kekerasan Terhadap Perempuan Berbasis Gender",. Rifka Annisa Bersama WPF.

[16] Eriyanti, L. D. (2017). Pemikiran Johan Galtung tentang Kekerasan dalam Perspektif Feminisme. Jurnal Hubungan Internasional, 6(1).

[17] Harkrisnowo, H. (2000). Tindakan Kekerasan terhadap Perempuan dalam Perspektif Sosio-Yuridis. Jurnal Hukum IUS QUIA IUSTUM, 7(14), 157-170. https://doi.org/10.20885/iustum.vol7.iss1 4.art11

[18] Perempuan, K. (2002). Peta Kekerasan : Pengalaman Perempuan Indonesia. AMeepro.

[19] DOMESTIK: (Studi Dokumen Penyebab Kekerasan pada Perempuan dalam Rumah Tangga di Pulau Bangka). 
Society,

5(1),

99-106.

https://doi.org/10.33019/society.v5i1.23 